\title{
The rise and ruin of unreasonableness?
}

\author{
Andrew Le Sueur \\ Barber Professor of Jurisprudence, The University of Birmingham
}

\section{Introduction}

Lest we forget what was actually said in 1948, Lord Greene stated: ${ }^{1}$

It is true to say that, if a decision on a competent matter is so unreasonable that no reasonable authority could ever have come to it, then the courts can interfere. That, I think, is quite right; but to prove a case of that kind would require something overwhelming ... It is not what the court considers unreasonable, a different thing altogether. If it is what the court considers unreasonable, the court may very well have different views to that of a local authority on matters of high public policy of this kind. Some courts might think that no children ought to be admitted on Sundays at all, some courts might think the reverse, and all over the country I have no doubt on a thing of that sort honest and sincere people hold different views. The effect of the legislation is not to set up the court as an arbiter of the correctness of one view over another. It is the local authority that are set in that position and, provided they act, as they have acted, within the four corners of their jurisdiction, this court, in my opinion, cannot interfere.

Put like this, unreasonableness as a ground of review is a straightforward concept, based on sound constitutional principles and a useful longstop to deal with a residual category of patently bad decisions. It makes abundantly clear that the courts are to make a secondary decision, with the primary decision about the merits of the matter being left to public authorities. The problem is that in the ensuing years we have heaped too much onto the unreasonableness test - we have attempted to make it too sophisticated, and we have used it to carry out tasks it was never intended to deal with (notably, adjudicating on claims made under s.6 of the Human Rights Act). Wednesbury unreasonableness is in danger of imploding under the weight of expectations.

The general criticisms of unreasonableness as a basis of review are well-known and often repeated: it is a circular definition; it is an uncertain guide as to the extent of the "margin of discretion" to be permitted to a public authority in any given situation or (the flip side of the coin) the intensity of review to be conducted by the court; it is a cloak which may tempt lawyers and courts to deal with the merits of grievances rather than questions of legality. These conceptual weaknesses have led to proposals for the common law to recognise a number of substantive principles in place of unreasonableness (e.g., equality) ${ }^{2}$ or for the replacement of the reasonableness test with one of proportionality. ${ }^{3}$

\footnotetext{
${ }^{1}$ Associate Provincial Picture Houses Ltd v Wednesbury Corp [1948] 1 KB 223.

${ }^{2}$ See J. Jowell and A. Lester, “Beyond Wednesbury: Substantive Principles of Administrative Law” [1987] P.L. 368.

${ }^{3}$ See the seminal essay by Jowell and Lester, "Proportionality: Neither Novel Nor Dangerous" in J. Jowell and
} 
Criticisms have also been made by the European Court of Human Rights. ${ }^{4}$ At home, our judges also make criticisms of Wednesbury or acknowledge the difficulties that beset it. In Daly, the prison cell searches case, Lord Cooke of Thorndon spared no punches: ${ }^{5}$

And I think that the day will come when it will be more widely recognised that Associated Provincial Picture Houses Ltd v Wednesbury Corporation [1948] 1 KB 223 was an unfortunately retrogressive decision in English administrative law, insofar as it suggested that there are degrees of unreasonableness and that only a very extreme degree can bring an administrative decision within the legitimate scope of judicial invalidation. The depth of judicial review and the deference due to administrative discretion vary with the subject matter. It may well be, however, that the law can never be satisfied in any administrative field merely by a finding that the decision under review is not capricious or absurd.

In April 2003 in R. (on the application of Association of British Civilian Internees (Far East Region)) $v$ Secretary of State for Defence the CA dealt, as a preliminary question, with whether proportionality exists as a separate ground of review in a case which does not concern Community law or human rights protected by the European Convention on Human Rights ("ECHR"). ${ }^{6}$ David Pannick QC, for the claimants "boldly submitted" that it does; for the Secretary of State it was submitted that the CA was bound by previous authority to hold that it did not. Giving the single judgment of the Court, Dyson L.J. said that although we did not hear argument on the point, we have difficulty in seeing what justification there now is for retaining the Wednesbury test. [35] But we consider that it is not for this court to perform its burial rites. The continuing existence of the Wednesbury test has been acknowledged by the House of Lords on more than one occasion".

The CA therefore went on to "approach the issues in the present appeal on the footing that the Wednesbury test does survive, and that this is the correct test to apply in a case such as the present which does not involve Community law, and does not engage any question of rights under the ECHR".

A month later in the House of Lords case R. (Pro-life Alliance) v $B B C$ appeal, challenging a refusal to screen a party political broadcast, Lord Walker said: ${ }^{7}$

The Wednesbury test, for all its defects, had the advantage of simplicity, and it might be thought unsatisfactory that it must now be replaced (when human rights are in play) by a much more complex and contextually sensitive approach. But the scope and reach of the Human Rights Act is so extensive that there is no alternative. It might be a mistake, at this stage in the bedding-down of the Human Rights Act, for your Lordships' House to go too far in attempting any comprehensive statement of principle. But it is clear that any simple "one size fits all" formulation of the test would be impossible.

The stage is therefore set for a conceptual battle between irrationality and proportionality and,

D. Oliver, eds., New Directions in Judicial Review (Stevens, London, 1988).

${ }^{4}$ See below.

${ }^{5}$ R. v Secretary of State for the Home Department Ex p. Daly [2001] UKHL 26; [2001] 2 A.C. 532.

${ }^{6}$ [2003] EWCA Civ 473; [2003] Q.B. 1397.

${ }^{7}$ [2003] UKHL 23; [2003] 2 W.L.R. 1403 (May 15, 2003). 
in relation to some unqualified Convention rights, merits review.

\section{Basic distinctions between domestic law and Convention rights}

For going further, it may be helpful to state the obvious. ${ }^{8}$ It is both possible and desirable to make a distinction between (a) situations where duties and rights stemming from English law are at stake and (b) those where Convention rights are relied upon. These two streams of law have different purposes. The orthodox grounds of judicial review in English law - those falling under the "chapter heads" of illegality, irrationality and procedural impropriety regulate the legality of public authority decision-making by guarding against violations of parliamentary intention or principles of embedded in the common law. The HRA was enacted for a different purpose, namely "to give further effect to rights and freedoms guaranteed under the" ECHR as amplified in the case law of the European Court of Human Rights.

The two streams of law are not, however, watertight categories. Many claimants rely on both domestic law and HRA grounds of review. Recent research shows that Convention rights are used in about half of all judicial review claims, though most often "to supplement established grounds for judicial review in cases that would have been pursued in any event on such grounds prior to the introduction of the HRA".

Moreover, judicial techniques and legal concepts for reviewing the substance of governmental decisions developed in one stream feed into the other. Such "leakage" may in some situations be appropriate, but it may also lead to problems - as it clearly has when courts attempted to use irrationality as a basis for dealing with claims under s.6 of the HRA. Table 1 sets out the fate of the unreasonableness review in handling Convention rights. Irrationality review has limited utility in this context.

Table 1: the fate of irrationality in Convention right contexts

\begin{tabular}{|c|c|c|c|}
\hline Art. 2 & $\begin{array}{l}\text { Art. } 3 \text { (at least in } \\
\text { immigration and } \\
\text { asylum) }\end{array}$ & $\begin{array}{l}\text { Art.5(4) (at least in } \\
\text { mental health cases) }\end{array}$ & Arts $8-11$ \\
\hline $\begin{array}{l}\text { The CA is close to } \\
\text { accepting that } \\
\text { irrationality review } \\
\text { must be so intense } \\
\text { that it is in effect } \\
\text { merits review (+ } \\
\text { some deference) }\end{array}$ & $\begin{array}{l}\text { Irrationality review } \\
\text { does provide an } \\
\text { effective remedy, but } \\
\text { there must be anxious } \\
\text { scrutiny. }\end{array}$ & $\begin{array}{l}\text { Irrationality review is } \\
\text { not an effective } \\
\text { remedy as it excludes } \\
\text { adequate examination } \\
\text { of merits }\end{array}$ & $\begin{array}{l}\text { Irrationality no } \\
\text { longer appropriate; } \\
\text { instead use } \\
\text { proportionality + } \\
\text { deference }\end{array}$ \\
\hline $\begin{array}{l}R .(B \log g s 61) v \\
S S H D \text { [2003] EWCA } \\
\text { Civ } 686\end{array}$ & $\begin{array}{l}R . v . S S H D \text { Exp } \\
\text { Thangarasa [2002] } \\
\text { UKHL } 36\end{array}$ & $\begin{array}{l}\text { HL } \vee \text { United } \\
\text { Kingdom, 5th } \\
\text { October } 2004\end{array}$ & $\begin{array}{l}R v \text { SSHD Exp Daly } \\
\text { [2001] UKHL } 26\end{array}$ \\
\hline
\end{tabular}

In relation to ECHR Art.2, in $R$ (Bloggs 61) v Secretary of State for the Home Department, which involved an Art. 2 claim, the Court of Appeal came close to accepting that the where

\footnotetext{
${ }^{8}$ See further Mark Elliott, "The Human Rights Act 1998 and the Standard of Substantive Review" (2001) 60 C.L.J. 301 (written before leading cases such as Daly and Alconbury).

${ }^{9}$ Public Law Project/Varda Bondy, The Impact of the Human Rights Act on Judicial Review: An Empirical Research Study (June 2003), p.31.
} 
the right to life is in issue ("the most fundamental of human rights") irrationality scrutiny may become so intense that it implodes into something almost indistinguishable from merits review, with the court becoming the primary decision-maker. ${ }^{10}$ The case concerned the removal of a prisoner from a "protected witness unit" into a mainstream prison and whether this would breach Art.2. Auld L.J. commented that

For what it is worth, I do not share the uncertainty of Ouseley J. [at first instance] as to how the court should decide the matter if the law had developed to the stage where it could make a decision on the merits for itself. I would have reached the same conclusion as the Prison Service, for the reasons it gave.

Keene L.J, agreeing, said:

... I agree, and would only wish to emphasise one aspect of the Article 2 issue. The right of life under that Article is an unqualified right and one which is self-evidently fundamental in nature. The issue is not, therefore, one of whether interference with the right can be justified on grounds of competing public considerations but simply whether it has been shown that there is or would be an interference with the right as a result of the decision of the Prison Service. In that sense it is very different from those cases where the courts are considering a claim that the public body has not struck the right balance between the individual's rights and the public interest, such as may arise where, for example, it is the right to respect for private and family life under Article 8 that is engaged.

I can see that in these circumstances it could be argued that it is for the court to make its own judgment as to whether there would be an interference with the right to life under Article 2, rather than making a judgment as to the reasonableness of the decision made by the Prison Service. The court is a public authority by virtue of section 6(3) of the Human Rights Act 1998 and cannot therefore act in a way which is incompatible with a Convention right. There is no direct authority in English law as yet on this issue, and it is to be observed that in the Pro-life case the House of Lords was dealing with an Article 10 case, where a balance was to be struck between the right to freedom of expression and the factors set out in Article 10(2). It was therefore not an unconditional right case. ...

Even were it to be the case that it is for the court to make that primary judgment, the reality is that the court would have to attach considerable weight to the assessment of risk made by those with professional involvement in the areas with which the case was concerned, which in the present case means the police and the Prison Service.

In relation to ECHR Art.3 (torture, inhuman or degrading treatment), the "anxious scrutiny" variant of irrationality is, however, recognised by the English courts ${ }^{11}$ and the Strasbourg court $^{12}$ as providing an effective remedy for the purposes of Art.13 in the context of immigration and asylum decisions. The Administrative Court is expected to arrive at its own conclusions on the facts, or at least examine the underlying facts rigorously to see if they compel a different conclusion to one reached by the decision-maker. ${ }^{13}$ Some margin of

\footnotetext{
${ }^{10}$ [2003] EWCA Civ 686; [2003] 1 W.L.R. 2724.

${ }^{11} R$. (Thangarasa) v Secretary of State for the Home Department [2002] UKHL 36.

${ }^{12}$ Vilvarajah $v$ UK [1991] EHRR 248.

${ }^{13}$ R. v Secretary of State for the Home Department Ex p. Turgut [2000] U.K.H.R.R. 403.
} 
discretion may be allowed to the decision-maker. ${ }^{14}$

ECHR Art.5(2) guarantees "Everyone who is deprived of his liberty by arrest or detention shall be entitled to take proceedings by which the lawfulness of his detention shall be decided speedily by a court and his release ordered if the detention is not lawful". In October 2004, the Strasbourg Court in HL v United Kingdom held that "super-Wednesbury"15 did not constitute an effective remedy for the purposes of Art.5(4) in a case where a person was "informally" detained without his consent in a mental hospital. ${ }^{16}$ The deficiency is that irrationality review excludes adequate examination of the merits of the claimant's case - here "the merits of the clinical views as to the persistence of mental illness justifying detention".

The domestic courts' approach in cases involving ECHR Arts 3 and 5 where a person's detention and treatment is dependent on clinical judgement has been rather different. In October 2001, the CA in $R$ (Wilkinson) v Broadmoor Special Hospital seemed to indicate that a merits review approach was required, with the court reaching its own view of the need for medical treatment on the basis of oral evidence from medical witnesses including crossexamination. ${ }^{17}$ Subsequent cases have sought to distinguish Wilkinson and emphasise that the court's role is one of supervisory not merits review. In other words, the court must avoid substituting its own discretion for that of the impugned public authority, albeit that in carrying out "the most anxious scrutiny", and "rigorously examining all the evidence", the court may have to form a view of its own on some matters of fact. ${ }^{18}$

In cases where a court is called upon to adjudicate on alleged failures to balance the considerations that must be taken into account in relation to the qualified Convention rights (principally ECHR Arts 8-11), and the question of what "is necessary in a democratic society". Here use of Wednesbury, even with anxious scrutiny, has been held not to provide an effective remedy; instead a proportionality test is to be used. This follows from Smith and Grady v United Kingdom in which the Strasbourg Court held that even intensive irrationality review was inadequate for the purposes of protecting rights under Art.8. ${ }^{19}$ The test did not allow the court adequately to assess whether the prohibition on gay men and women serving in the armed forces could be justified on the basis of social need, national security or public order. Initially, in Mahmood, ${ }^{20}$ the Court of Appeal may have fail to see the full implications of the Strasbourg decisions in Smith and Lustig-Prean, but the position was "clarified" by the House of Lords in Daly. ${ }^{21}$

\footnotetext{
${ }^{14}$ See the exchange of views in Public Law: I. Leigh, "Taking Rights Proportionately: Judicial Review, the Human Rights Act and Strasbourg" [2002] P.L. 265 and S. Atrill, "Keeping the Executive in the Picture" [2003] P.L. 41.

${ }^{15}$ See below.

${ }^{16}$ Application 45508/99 (5 October 2004), arising from Re L [1999] 1 A.C. 458 (HL), [1998] 2 W.L.R. 764 (CA).

${ }^{17}$ [2001] EWCA Civ 1545; [2002] 1 W.L.R. 419.

${ }^{18}$ See e.g. $R(I R) v$ Shetty [2003] EWHC 3022, Munby J (whether the claimant suffering severe psychotic episodes could lawfully be transferred to prison from a psychiatric clinic); Claire F $v$ Secretary of State for the Home Department [2004] EWHC 111, Munby J (whether lawful for a baby to be separated from her mother who was serving a long sentence of imprisonment - it was not the court's function to come to its own assessment of what is in the child's best interests).

${ }^{19}$ Smith v UK [1999] I.R.L.R. 734 and Lustig-Prean v UK (2000) 29 E.H.R.R. 548.

${ }^{20} R$ (Mahmood) $v$ Secretary of State for the Home Department [2001] 1 W.L.R. 840, CA.

${ }^{21}$ R. $v$ Secretary of State for the Home Department Ex p. Daly [2001] UKHL 26; [2001] 2 A.C. 532.
} 


\section{Irrationality in domestic contexts}

In the rest of this paper, I focus on the operation of unreasonableness review in domestic contexts (i.e., where Convention rights do not feature or at least are not at the forefront of the claimant's case). At the outset, however, it must be acknowledged that Convention rights may exert an influence here (even leaving aside the speculative question, whether in time proportionality will come to be the main judicial tool in domestic law as well as qualified Convention right situations).

\section{Using Convention rights to get anxious scrutiny}

First, claimants may argue that a Convention right is engaged, though hold back from deploying a fully fledged argument based on breach of the Convention right in question, in order to benefit from the "anxious scrutiny" approach to Wednesbury that had been established several years before the HRA in relation to "fundamental rights". ${ }^{22}$ A good illustration is $R . v$ (Anne) $v$ Test Valley $B C$ where the husband and wife claimants said that their rights under ECHR Arts 2 and 8, along with Art. 1 of the First Protocol were affected. ${ }^{23}$ The claimants argued that the council had unlawfully refused permission to fell a large lime tree in a neighbour's garden, spores from which, the claimants said, were seriously harming the wife's health and the thatched roof of their cottage. Forbes J. noted that counsel for the claimants

has expressly confined his submissions and the case to the challenge on rationality grounds and has argued that, since the relevant complaint was one which did concern matters involving the various Convention rights to which I have referred earlier in this judgment, the court should give "anxious scrutiny" to the decision-making process in question, when considering whether the conclusions reached are susceptible to challenge on grounds of rationality. In the circumstances of this case, I am content to approach the matter on that basis. It is, therefore, unnecessary for me to express any concluded view as to whether that is necessarily the correct approach.

Forbes J. went on to look at the evidence in considerable detail, holding that the council had not acted irrationally. This approach has the potential to increase the frequency with which courts engage in "anxious scrutiny" Wednesbury review. I return to the general issue below.

\section{Courts of "full jurisdiction"}

A second Convention right influence on Wednesbury review of domestic law duties and rights comes from Art.6(1). This guarantees that "In the determination of his civil rights and obligations ...., everyone is entitled to a fair and public hearing ... by an independent and impartial tribunal". Some - but not all - claims for judicial review involve "civil rights and obligations". Whether a claim does or not may be "a very difficult question". ${ }^{24}$ In Alconbury, Lord Clyde accepted that ${ }^{25}$

\footnotetext{
${ }^{22}$ See below.

${ }^{23}$ [2001] EWHC Admin 1019, [2002] Env.L.R. 22.

${ }^{24} R$ (Begum) v Tower Hamlets LBC [2003] UKHL 5; [2003] 2 A.C. 430 at [82] (Lord Millett).

${ }^{25}$ R. $v$ Secretary of State for the Environment, Transport and the Regions Ex p. Holdings \& Barnes Plc ("Alconbury") [2001] UKHL 23; [2003] 2 A.C. 295 at [150].
} 
It is thus clear that article 6(1) is engaged where the decision which is to be given is of an administrative character, that is to say one given in an exercise of a discretionary power, as well as a dispute in a court of law regarding the private rights of the citizen, provided that it directly affects civil rights and obligations and is of a genuine and serious nature.

Disputes with the Inland Revenue over tax affairs do not, according to the Strasbourg court, ${ }^{26}$ though Lord Walker doubts whether this is correct (and so do I). ${ }^{27}$ In the town and country planning context, development plan policies are not "directly decisive" of a claimant's rights, and so fall outside the protective ambit of Art.6(1). ${ }^{28}$ In cases involving a possession orders sought by a local authority, the position is far from clear (as the House of Lords acknowledged in February 2003). ${ }^{29}$

The whole relationship between "civil rights and obligations" and claims for judicial review is clearly one to which the English courts must return. ${ }^{30}$ There are many square pegs and round holes here. Problems arise because Art.6(1) was not designed to deal with claims relating to the legality of public authority administrative decisions; it "was intended to be supplemented by further measures in relation to the making of administrative decisions", ${ }^{31}$ but these have not been forthcoming from the Council of Europe. Furthermore, the concept of "civil rights and obligations", while perhaps making sense in civilian legal systems, sits uneasily with the basic categories of a common law system.

This is not the place to examine Art.6(1) in detail. The main point for present purposes is to note that if Art.6(1) is engaged, then a claimant is entitled to a court of "full jurisdiction" and "judicial control" over the legality of the disputed decision. This does not necessarily require a complete rehearing on the merits. As Lord Hoffmann put it in Alconbury, what is needed is "jurisdiction to deal with the case as the nature of the decision requires". 32

The Administrative Court, using Wednesbury review, may in some contexts be expected to consider questions of fact more closely than it otherwise would have done. The CA in McLellan (where possession was sought by the council against a claimant who had an "introductory tenancy") held: ${ }^{33}$

Where facts can be established with certainty, for example rent arrears, the question as to the reasonableness of a decision to terminate an introductory tenancy will be suitable for determination on judicial review. However, if the council in providing reasons alleges acts that are disputed, then that may raise issues of fact. ... The right question under the scheme will be whether in the context of allegation and counter-

\footnotetext{
${ }^{26}$ Ferrazzini v Italy (2002) 34 EHRR 45 held the concept of "civil rights and obligations" under Art. 6(1) did not extend to cover disputes between citizens and public authorities as to the lawfulness under domestic law of tax authorities' decisions as 'tax matters still formed part of the hard core of public-authority prerogatives, with the public nature of the relationship between the tax payer and the tax authority remaining predominant". See also A. Le Sueur, "Appeals and Judicial Review after the Human Rights (Jersey) Law 2000” [2002] Jersey Law Review 142.

${ }^{27} R$ (Begum) v Tower Hamlets LBC [2003] UKHL 5; [2003] 2 A.C. 430.

${ }^{28} R$. (Aggregate Industries UK Ltd) v English Nature [2002] EWHC 908 Admin; [2002] A.C.D. 67 (p. 403 ).

${ }^{29} R$ (Begum) v Tower Hamlets LBC [2003] UKHL 5; [2003] 2 A.C. 430.

${ }^{30}$ For a general discussion, see J. Herberg, A. Le Sueur and J. Mulcahy, "Determining Civil Rights and

Obligations" in J. Jowell and J. Cooper, eds., Understanding Human Rights Principles (Hart Publishing, 2001).

${ }^{31}$ See R. (Begum) v Tower Hamlets LBC [2003] UKHL 5; [2003] 2 A.C. 430 at [28] and [86].

${ }^{32}$ Alconbury at [87].

${ }^{33}$ R. (McLennan) v Bracknell Forest BC [2001] EWCA Civ 1510, [2002] A.C.D.54 (p.332), [H41].
} 
allegation it was reasonable for the council to take a decision to proceed with termination of the introductory tenancy. That again is a matter which can be dealt with under judicial review either of the traditional kind or if it is necessary to do so intensified so as to ensure that the tenant's rights are protected.

In the later HL case of Begum, the issue was different: the council's obligation under the Housing Act 1996 where a homeless person refuses a secure tenancy offered by the council under its duty to homeless people, on the ground that the accommodation offered was unsuitable. The claimant said that the decision reached by the council's reviewing officer, following an internal procedure, was irrational. Lord Hoffmann, with whom the other members of the Appellate Committee agreed, said: ${ }^{34}$

[47] Although I do not think that the exercise of administrative functions requires a mechanism for independent findings of fact or a full appeal, it does need to be lawful and fair. ... In any case, the gap between judicial review and a full right of appeal is seldom in practice very wide. Even with a full right of appeal it is not easy for an appellate tribunal which has not itself seen the witnesses to differ from the decisionmaker on questions of primary fact and, more especially relevant to this case, on questions of credibility... [49] No doubt it is open to a court exercising the review jurisdiction [conferred on county courts, but the same in scope as CPR 54] to adopt a more intensive scrutiny of the rationality of the reviewing officer's conclusions of fact but this is not the occasion to enter into the question of when it should do so. When one is dealing with a welfare scheme which, in the particular case does not engage human rights (does not, for example, require consideration of Art.8) then the intensity of review must depend upon what one considers to be the most consistent with the statutory scheme. ...[50] All that we are concerned with in this appeal is the requirements of Art.6, which I do not think mandates a more intensive approach to judicial review of questions of fact. These nuances are well within the margin of appreciation which the Convention allows to contracting states and which, in a case like this, the courts should concede to Parliament. So I do not propose to say anything about whether a review of fact going beyond conventional principles of judicial review would be either permissible or appropriate. It seems to me sufficient to say that in the case of the normal Part VII [of the Housing Act 1996] decision, engaging no human rights other that Art.6, conventional judicial review such as the Strasbourg court considered in the Bryan case (1995) 21 E.H.R.R. 342 is sufficient. 


\section{The development of "anxious scrutiny"}

Clearly, in predominantly domestic law situations, the effectiveness of unreasonableness argument will be linked to the intensity with which the court in evaluates the facts, reasoning and conclusions of the public authority. There are today four many categories controlling intensity of review.

Table 2: intensity of review

\begin{tabular}{|c|c|}
\hline Type of review & Test \\
\hline Non-justiciable & $\begin{array}{l}\text { For a recent case, see e.g. R. (on the application of Campaign for Nuclear } \\
\text { Disarmament) v Prime Minister [2002] EWHC 2777; [2003] A.C.D. } 36 .\end{array}$ \\
\hline $\begin{array}{l}\text { super- } \\
\text { Wednesbury }\end{array}$ & $\begin{array}{l}\text { "so absurd that the decision-maker must have taken leave of his senses" } \\
\text { (Nottinghamshire CC [1986] AC 240) } \\
\text { "The greater the policy content of a decision, and the more remote the } \\
\text { subject matter of a decision from ordinary judicial experience, the more } \\
\text { hesitant the court must necessarily be in holding a decision to be } \\
\text { irrational. That is good law and, like most good law, common sense. } \\
\text { Where decisions of a policy-laden, esoteric or security-based nature are in } \\
\text { issue, even greater caution than normal must be shown in applying the } \\
\text { test, but the test itself is sufficiently flexible to cover all situations" } \\
\text { (Bingham in Smith) }\end{array}$ \\
\hline $\begin{array}{l}\text { basic } \\
\text { Wednesbury }\end{array}$ & $\begin{array}{l}\text { "... a decision that elicits the exclamation 'my goodness, that is certainly } \\
\text { wrong!" } R . v \text { Devon CC ex p. George [1989] A.C. } 573 \\
\text { "so outrageous in its defiance of logic or of accepted moral standards that } \\
\text { no sensible person who had applied his mind to the question to be decided } \\
\text { could have arrived at it" (CCSU v Minister for the Civil Service [1985] } \\
\text { AC } 374 \text { at } 410 \text { per Lord Diplock) }\end{array}$ \\
\hline $\begin{array}{l}\text { "anxious } \\
\text { scrutiny", } \\
\text { "enhanced level } \\
\text { scrutiny", } \\
\text { "rigorous } \\
\text { examination" }\end{array}$ & $\begin{array}{l}\text { "Reasonableness in such cases is not, however, synonymous with } \\
\text { 'absurdity' or 'perversity'. Review is stricter and the courts ask the } \\
\text { question posed by the majority in Brind, namely, 'whether a reasonable } \\
\text { Secretary of State, on the material before him, could reasonably conclude } \\
\text { that the interference with freedom of expression was justifiable'. This test } \\
\text { lowers the threshold of unreasonableness. In addition, it has been held that } \\
\text { decisions infringing rights should receive the 'most anxious scrutiny' of } \\
\text { the courts." de Smith, Woolf and Jowell, Judicial Review of } \\
\text { Administrative Action 5th Edition at para 13-060, approved by Roch L.J. } \\
\text { in } R \text {. } v \text {. Saville Inquiry Exp. A and others [1999] EWHC Admin 556, } \\
\text { Can the decision 'confidently enough said to have been correct'? (Gurung } \\
v \text { Secretary of State for the Home Department [2003] EWCA Civ 654, } \\
\text { Buxton L.J.). } \\
\text { The court may not interfere with the exercise of an administrative decision } \\
\text { on substantive grounds save where the court is satisfied ... that it is beyond } \\
\text { the range of responses open to a reasonable decision-maker but in judging } \\
\text { whether the decision-maker has exceeded this margin of appreciation the } \\
\text { human rights context is important. The more substantial the interference } \\
\text { with human rights, the more the court will require by way of justification } \\
\text { before it is satisfied that the decision is reasonable in the sense outlined } \\
\text { above. (R. } v \text { Ministry of Defence Exp Smith, per Sir Thomas Bingham) }\end{array}$ \\
\hline
\end{tabular}


When the variable intensity approach to unreasonableness was first propounded by Lord Bridge in R. $v$ Secretary of State for the Home Department Ex p. Bugdaycay, ${ }^{35}$ it is likely that this variant on the orthodox approach would be used in comparatively rare situations. In that case "human life or liberty was at risk". Prior to the HRA, one had to find a "fundamental right" recognised by the common law, or perhaps recognised as a norm of international law, in order to kick start an anxious scrutiny argument. Today, surely almost all such common law rights have broadly corresponding Convention rights and these dominate our thinking about fundamental rights. While unreasonableness continues to be used for claims made on Arts 2 and 3 (see above), and while the judicial review case load remains dominated by immigration and asylum matters, the nominated judges will spend a considerable proportion of their time using the anxious scrutiny approach. It is no longer a test held in reserve for unusual situations. It may not be too much of an exaggeration to say that there is now as much anxious scrutiny as there is orthodox unreasonableness adjudication in the Administrative Court, certainly if one puts applications for permission into the equation.

The attempt at fine tuning, set out in Table 2, creates a number of conceptual challenges and problems.

First, should the varying degrees of intensity be regarded as categories, or is it better to view them as points along a spectrum? In Mahmood, Laws L.J. was clear that there is a spectrum. Referring to the Smith formula, he said: ${ }^{36}$

that approach and the basic Wednesbury rule are by no means hermetically sealed the one from the other. There is, rather, what may be called a sliding scale of review; the graver the impact of the decision in question upon the individual affected by it, the more substantial the justification that will be required.

Of course, we all know that in judicial review "context is everything". I have some doubts, however, whether a sliding scale approach is the best one. Arguably, recognising categories may make it easier for there to be a principled and more certain approach to the court's role: if situation A then intensity B, rather than slithering around in grey areas.

Secondly, there is a problem of deciding into which category, or where on the sliding scale, a case sits. This is often obvious, but is sometimes contested. In Smith, the counsel for the gay servicemen and women contended for anxious scrutiny, while the Ministry of Defence argued for a super-Wednesbury test to be applied; the former prevailed because the policy was not one that "depends essentially on political judgment" and, distinguishing the Nottinghamshire case, the human rights dimension was "prominent". ${ }^{37}$ More recently in Javed, the challenge was to delegated legislation designating Pakistan, for the purposes of returning asylum seekers, as a country in which there was "in general no serious risk of persecution". The Order had been subject to short debates in both the Commons and the Lords. For the Secretary of State it was contended that super-Wednesbury was the appropriate intensity of review: the matter related to policy considerations affecting the UK's foreign relations; moreover, a more intensive approach would be inconsistent with article 9 of the Bill of Rights 1689. The claimants argued for anxious scrutiny. The CA plumped for ordinary

\footnotetext{
${ }^{35}$ [1987] AC 514.

${ }^{36}$ Mahmood, above, at [19].

${ }^{37}$ [1995] 4 All ER 427 per Simon Brown L.J. Div. Ct. Curtis J. held that ordinary Wednesbury should govern the situation; in the CA all were agreed that the anxious scrutiny approach applied.
} 
Wednesbury (and went on to hold the legislation unreasonable). In the Medway case ${ }^{38}$ Maurice Kay J. stated, having held that it was unreasonable to exclude Gatwick from the options offered for consultation over expansion of airport capacity:

I make it clear that, although I have in mind the importance of the future development of air transport and my duty to detach myself from the ultimate policy merits, I do not accept [the] submission that the questions raised by this case are matters of such high policy that the are challengeable only the basis of bad faith (which is not alleged) .... I consider them to be reviewable on traditional judicial review grounds although I accept that it behoves me to approach them with particular care.

In Begum, discussed above, Lord Bingham warned: ${ }^{39}$

I can see no warrant for applying in this context notions of "anxious scrutiny" ... or the enhanced approach to judicial review described by Lord Steyn in $R$ (Daly) $v$ Secretary of State for the Home Department [2001] 2 AC 532, 546-548. I would also demur at the suggestion of Laws LJ in the Court of Appeal in the present case ([2002] EWCA Civ 239, [44]) that the judge may subject the decision to "a close and rigorous analysis" if by that is meant an analysis closer or more rigorous that would ordinarily and properly be conducted by a careful and competent judge determining an application for judicial review.

There is, then, considerable scope for judicial disagreement and, as yet, perhaps insufficiently developed principles to guide the choice.

Thirdly, there is the question of what anxious scrutiny actually requires the court to do. It is a "mantra" so frequently invoked by counsel and the courts that there is a risk of forgetting, or never discovering, what it entails - or else end up paying only lip service to it. ${ }^{40}$ The following principles can be extracted from the case law.

- A "common sense" approach is to be taken: anxious scrutiny "does not mean that the court should strive by tortuous mental gymnastics to find error in the decision under review when in truth there has been none". ${ }^{4}$

- "The concern of the court ought to be substance not semantics". Nor is it appropriate to focus "on particular sentences" in a decision-maker's determination "and to subject them to the kind of legalistic scrutiny that might perhaps be appropriate in the case of a statutory instrument, charter party or trust deed". ${ }^{42}$ But while it would be wrong to interpret the decision of a decision maker "in a minute textual fashion, ... it must be right in every case to see whether substantial and proper reasons are given". 43

- The court's role remains one of review for error of law. ${ }^{44}$

\footnotetext{
${ }^{38}$ R. (Medway Council and others) $v$ Secretary of State for Transport [2002] EWHC 2516 Admin; [2003] J.P.L. 583 at [18]

${ }^{39} R$ (Begum) v Tower Hamlets LBC [2003] UKHL 5; [2003] 2 A.C. 430.

${ }^{40} R$. v Secretary of State for the Home Department Ex p. Sivakumar (FC) [2001] EWCA Civ 1196,[2002]

I.N.L.R. 310 (and an appeal to the HL, see [2003] UKHL 14).

${ }^{41} R$. (Sarkisian) v IAT [2001] EWHC Admin 486, Mumby J.

${ }^{42} R$ (Puspalatha) v IAT [2001] EWHC Admin 333 at [43], Sullivan J.

${ }^{43} R$. (Kurecaj and another) $v$ Secretary of State for the Home Department [2002] EWHC 1199 Admin, Gibbs J.

${ }^{44} R$ (Puga) v IAT [2001] EWCA Civ 931, Laws L.J.: "[31] As is well known, in 1987 Lord Bridge said in the case of Musisi [1987] 1 AC 514 that these cases need to be approached with anxious scrutiny, given what may be involved. And so they must. But as a reading of his Lordship's speech in that case readily demonstrates, the
} 
- The burden of argument shifts from the claimant to the defendant public authority. The claimant no longer has to demonstrate unreasonableness, but rather the defendant needs to produce a justification for the decision that satisfies the court that it was properly made (with the court according the public authority appropriate "deference").

- The court is not a fact-finder (though it may have regard to factual material not before the primary decision-maker). ${ }^{45}$

- The Court will be less inclined to accept ex post facto justifications from the public authority, compared to ordinary reasonableness. ${ }^{46}$

The challenge is to achieve enhanced review without (a) turning the exercise into an appeal on the merits of the decision or (b) slipping into an approach based on proportionality rather than reasonableness.

Table 3: Types of judicial control

\begin{tabular}{|c|c|}
\hline Type of judicial control & Main features \\
\hline $\begin{array}{l}\text { "Anxious" or } \\
\text { "enhanced" } \\
\text { irrationality review }\end{array}$ & $\begin{array}{l}\text { The issue remains whether the public authority's } \\
\text { decision is within a reasonable range of options. }\end{array}$ \\
\hline $\begin{array}{l}\text { Proportionality review } \\
\text { —whether: (i) the objective is } \\
\text { sufficiently important to } \\
\text { justify limiting a fundamental } \\
\text { right; (ii) the measures } \\
\text { designed to meet the } \\
\text { objective are rationally } \\
\text { connected to it; and (iii) the } \\
\text { means used to impair the } \\
\text { right or freedom are no more } \\
\text { than is necessary to } \\
\text { accomplish the objective. }{ }^{47}\end{array}$ & $\begin{array}{l}* \text { Court itself may need to assess the balance public } \\
\text { authority has struck between competing interests, not } \\
\text { merely consider whether that balance is reasonable. } \\
* \text { Court may have regard to the relative weight of the } \\
\text { various considerations taken into account. }\end{array}$ \\
\hline Merits review/appeal & $\begin{array}{l}\text { Court becomes the primary fact finder and decision- } \\
\text { maker }\end{array}$ \\
\hline
\end{tabular}

Fourthly, there is the problem of mismatch between the category the court fits at case into and the approach it actually takes. In Smith, Simon Brown L.J. at first instance, having held that an anxious scrutiny approach was appropriate, nevertheless went on to use language that reads (and had the effect) much like ordinary irrationality review: ${ }^{48}$

Only if it were plain beyond sensible argument that no conceivable damage could be done to the armed services as a fighting unit would it be appropriate for this court now

court's role remains one of review for error of law. There is no error of law here."

${ }^{45}$ Polat $v$ Secretary of State for the Home Department [2003] All ER (D) 254 (Jul).

${ }^{46} R$ (Leung) v Imperial College of Science, Technology and Medicine [2002] EWHC 1358 Admin, [2002] ELR 653)

${ }^{47}$ See de Freitas $v$ Permanent Secretary of Ministry of Agriculture [1999] 1 A.C. 69, approved by Lord Steyn in Daly, above.

${ }^{48}$ [1995] 4 All ER 427, Div. Ct. 
to remove the issue entirely from the hands both of the military and of the government. ... With all these considerations in mind, I have come finally to the conclusion that, my own view of the evidence notwithstanding, the minister's stance cannot properly be held unlawful. His suggested justification for the ban may to many seem unconvincing; to say, however, that it is outrageous in its defiance of logic is another thing. There is, I conclude, still room for two views. Similarly it is difficult to regard the policy as wholly incompatible with 'accepted moral standards'.

A case that is arguably in the other direction is Medway. ${ }^{49}$ Maurice Kay J. explicitly applied ordinary Wednesbury, but it strikes me that was required by the court from the Secretary of State was something akin to the intensity found in the anxious/enhanced scrutiny cases.

\section{The every day use of unreasonableness}

So for this paper has focused on a relatively small number of well-known cases to sketch out the modern architecture for unreasonableness arguments. I want now to move on to see what is happening "on the ground" in domestic cases; I do this by looking at a sample of 41 judicial review cases decided between January 2000 and July 2003 (set out in the Appendix, below). Cases involving unreasonableness arguments in relation to Convention rights have been excluded. In most cases, a ground of review based on irrationality is added as a final supplement to others arguments, rather than being the main basis of challenge. In selecting the cases I have however attempted to disentangle unreasonableness points from others.

Unreasonableness arguments in the sample cases had a reasonably high success rate: claimants succeeded on this ground in 18 cases and failed in 23. The sample may perhaps be unrepresentative in several respects, including because the law report editors are more likely to select cases in which this argument is successful. Nevertheless, given what is often described as the high "threshold" of the unreasonableness test, is it not surprising that claimants seem to succeed in a relatively large proportion of cases?

\section{Concluding remarks}

For the reasons I have set out above, I believe that unreasonableness is struggling to survive as a coherent and useful ground of review. Its days are surely numbered as a tool for dealing with Convention rights claims: proportionality or merits review look set to step in (according to the nature of the Convention right engaged). Even in relation to domestic law judicial review, too much seems to be required of the unreasonableness ground. Without developing a particularly robust set of principles to guide it, the apparatus for variable intensity - supraWednesbury, ordinary Wednesbury, anxious scrutiny - seems less than clear in practice.

In considering the medium term future of Wednesbury unreasonableness in relation to domestic law judicial review claims, one can envisage several possibilities. First, the law, having developed in sophistication, may remain broadly static over the next 15 years or so. The courts may be content to let the last big innovation - variable intensity review - bed down. Secondly, the common law on rationality review may continue to evolve. As I have suggested, the approach to anxious scrutiny would benefit from further conceptual

${ }^{49}$ R. (Medway Council and others) v Secretary of State for Transport [2002] EWHC 2516 Admin; [2003] J.P.L. 583 at [18] 
clarification. Thirdly, the whole concept of irrationality as a basis of review in domestic law judicial review may be abandoned by the courts in favour of a proportionality test similar to that used in relation to qualified Convention right cases. Fourthly, if central government remains concerned about the unpredictability of irrationality review, there is always the possibility that legislation may be introduced to restrict the use of unreasonableness as a ground of judicial review in relation to some decision-making schemes, to the extent permitted by Convention rights. ${ }^{50}$

\section{APPENDIX: Sample of Wednesbury unreasonableness/irrationality cases January 2000-July 2003}

This survey has been compiled using the Current Legal Information CD-Rom searching for the words "irrational", "irrationality", "rational", "unreasonable" and "Wednesbury". The summaries are based closely on those provide by CLI.

\section{UNREASONABLENESS FOUND:}

Bosworth Beverages Ltd v Customs and Excise Commissioners [2001] V. \& D.R. 491. Held: unreasonable. Customs were entitled to prohibit any sales that would involve removal of the goods from a bonded warehouse but Reg.17(3) of the Excise Warehousing (etc) Regulations 1988 did not give Customs the authority to prohibit in warehouse transfers of goods because there was no threat to the revenue if the goods did not leave the warehouse. The second part of the direction merely required the giving of notice to Customs prior to a transfer out of B's account. It did not prohibit a transfer in bond to $\mathrm{M}$ within the warehouse. The Commissioners acted ultra vires in purporting to exercise such a power. It was for the bonded warehouse to ensure that excise duty payable on removal was paid and the Commissioners had acted Wednesbury unreasonably in failing to take this into account in restricting transfers within the warehouse.

R. (on the application of F) v Special Adjudicator [2002] EWHC 777; [2002] Imm. A.R. 407. Held: unreasonable. F sought judicial review of the special adjudicator's refusal to adjourn the hearing of her asylum appeal and his dismissal of her appeal against the Secretary of State's certification of her claim. F was a citizen of Kosovo, raped by three Serbian soldiers leaving her psychiatrically injured. Her application for asylum had been refused. At the hearing before the special adjudicator she sought an adjournment to obtain a report from a psychiatrist, which was to be available within a few days and preliminary indications of which were favourable to $F$. The special adjudicator refused the adjournment and stated that he would not take such a report into account even if it were sent to him after the hearing. The special adjudicator's decisions were quashed and the certificate was set aside. It was Wednesbury unreasonable to refuse the adjournment or later consideration as the delay was slight and on the facts acceptable. The refusal of the adjournment inevitably prevented $\mathrm{F}$ from presenting relevant and potentially cogent evidence in favour of her appeal.

R. (on the application of M) v Criminal Injuries Compensation Authority [2002] EWHC 2646; (2003) 100(2) L.S.G. 31. H applied for judicial review of the Criminal Injuries Compensation Authority's failure to determine his claim within a reasonable time. $\mathrm{H}$, an infant proceeding by his adoptive mother, had applied to CICA for compensation in relation to severe brain injuries suffered as a result of his being shaken by one of his natural parents. Held: the failure of CICA to determine H's claim expeditiously was Wednesbury unreasonable.

R. (on the application of H) v Ashworth Hospital Authority [2002] EWCA Civ 923; [2003] 1 W.L.R. 127. Held: the Mental Health Review Tribunal had acted unreasonably in failing to consider the availability of suitable after care and accommodation when deciding to order H's immediate discharge. Where a tribunal had doubts as to whether such services would be available on discharge, it should adjourn so as to obtain the necessary

\footnotetext{
${ }^{50}$ cf. in Australia, the Migration Act 1958, s.476(2), upheld by the High Court of Australia in Abebe v The Commonwealth (1999) 162 A.L.R. 1 and in the UK the proposed ouster clause in the Immigration and Asylum (Treatment of Claimants etc) Bill 2004, on which see A Le Sueur, "Three strikes and it's out? The UK government's strategy to oust judicial review from immigration and asylum decision-making” [2004] PL 225.
} 
information.

R. (on the application of National Association of Colliery Overmen Deputies and Shotfirers) v Secretary of State for Work and Pensions [2003] EWHC 607. N sought judicial review of the Secretary of State's decision not to immediately modify and revise the guidance given in the Notes on the Diagnosis of Prescribed Diseases, NDPD, on the use of the Cold Water Provocation Test as a diagnostic tool for vibration induced white finger in claims for industrial injuries benefits under the Social Security Contributions and Benefits Act 1992 s.108. Held, the decision was irrational. the court declined to pronounce on whether the cold water provocation test had become obsolete. However, no medical evidence existed to support the test as a useful diagnostic tool; (2) The Secretary of State had intended MAs to only treat the test as an opportunity for the claimant to demonstrate the existence of white finger. However, without clear guidance, MAs and decision makers might continue to be influenced by the results of the test, and (3) the decision not to amend the existing NDPD was founded upon a failure to take account of material consideration, namely that, on proper analysis, the evidence established that MAs appeared to have placed reliance on the test as a negative diagnostic tool. Although the NDPD did not state that the test was a diagnostic tool, in the absence of additional guidance there was a danger that it might be construed as indicating that a negative result could provide evidence that vibration induced white finger was not present. The NDPD should have been modified so as to clearly stipulate that the test should be treated as having no diagnostic value

R. (on the application of Cream) v General Medical Council [2002] EWHC 436; [2002] Lloyd's Rep. Med. 292. $\mathrm{C}$, a consultant dermatologist, applied for judicial review of the decision of the Professional Conduct Committee that he had been guilty of serious professional misconduct when he passed information to an appointments committee concerning the conduct of a colleague which subsequently proved to be false. $\mathrm{C}$ argued that the decision was irrational or one which no reasonable committee would have reached. Held: the GMC had acted irrationally. Under the GMC's good practice statement, Good Practice Guide 1998 it was not incumbent on a doctor to take any steps to inform himself further as to the facts until he had decided to take action. Even on a straightforward and uncomplicated understanding of the statement, it would be absurd for a doctor who had received unspecific rumour to investigate either its provenance or truth.

R. (on the application of Kelsall) v Secretary of State for the Environment, Food and Rural Affairs [2003] EWHC 459. K, a former mink farmer, sought judicial review of the Fur Farming (Compensation Scheme) (England) Order 2002, which provided a scheme for compensating farmers for business lost as a result of the implementation of the Fur Farming (Prohibition) Act 2000. K contended that the provisions of the scheme were unfair, irrational and discriminatory in so far as they (1) failed to compensate for the value of breeding males; (2) failed to recognise special breeds, and (3) reduced compensation according to the date of cessation of business. Held: the decision to pay no compensation in respect of breeding males was irrational given the fact that the income arising from the breeding of mink necessarily required male as well as female mink and the fact that breeding males were worth more than breeding females ...

R. (on the application of Medway Council) v Secretary of State for Transport, Local Government and the Regions [2002] EWHC 2516; [2003] J.P.L. 583. Held: the decision was irrational in that one of the reasons for the exclusion was that Gatwick could not be made a hub airport within the appropriate time frame when the consultation document made it clear that there was no decision to promote a hub airport. Furthermore, it was premature to exclude the Gatwick option at this stage since the aim of the consultation period was to refine various assumptions. It was procedurally unfair to operate the consultation process in such a way so as to effectively prevent the applicants from advocating Gatwick as an alternative solution at a later stage in the decision making process. The decision was also irrational in view of the conservation and environmental importance of the proposed alternative site in Kent and the obligation imposed by the Conservation (Natural Habitats \&c) Regulations 1994 Reg.48 and Reg.49 on the planning authority to consider any reasonable alternatives which would include Gatwick.

R. (on the application of Gurung) v Ministry of Defence [2003] EWHC 2463; (2003) 100 L.S.G. 25. G and other Nepalese nationals sought judicial review of the decision of the MoD to exclude them from the scheme awarding ex gratia compensation to former prisoners of war of the Japanese. $G$ had been recruited in Nepal for service in the Indian army under the auspices of the British Government and, before being captured, had served in a Gurkha rifle brigade. In 1955 the Gurkhas were excluded from compensation arrangements made in 1951 on the ground that they were paid and treated like any other sepoy, namely according to the colonial Indian military law. $G$ argued, inter alia, that his exclusion from the scheme amounted to an irrational departure from common law principles relating to equality of treatment. Held: the Gurkhas' allocation to the colonial military law in 1955 had been based on their race and the continued reliance on that argument undermined the rationality of 
their exclusion from the scheme. The exclusion of Nepalese nationals from the scheme was irrational and inconsistent with the principle of equality that formed the cornerstone of United Kingdom law.

R. v Secretary of State for the Home Department Ex p. Javed [2001] EWCA Civ 789; [2002] Q.B. 129. Inclusion of Pakistan on 'white list' under Asylum (Designated Countries of Destination and Designated Safe Third Countries) Order 1996 (SI 1996 2671). Held: subordinate legislation that had been approved by affirmative resolution of both Houses of Parliament could be subject to judicial review on the grounds of illegality, procedural impropriety or Wednesbury unreasonableness. The extent of any review on the ground of rationality would be dependent on the nature and purpose of the empowering Act. It was apparent, in the instant case, that the Secretary of State's decision should not be subjected to over zealous scrutiny. Having regard to evidence concerning the treatment of women and of the Ahmadis, a minority religious group, the Secretary of State had been irrational in his conclusion.

Hambleton DC v Secretary of State for the Environment, Transport and the Regions [2002] P.L.C.R. 1. H issued enforcement notices alleging unauthorised change of use of land by the owners, A, who had moved a residential caravan, market trader's caravan and a refrigeration unit on to the land from which they wanted to run a free range egg business. A's appeals against the notices were allowed by the inspector because he found that there was a sound financial basis for the business that did not conflict with the local plan. Held: varying the second notice by allowing the trader's caravan and refrigeration unit was irrational, however, as the inspector had already decided that it would be inappropriate to impose conditions on the permission in the instant case.

Richmond upon Thames LBC v Secretary of State for the Environment, Transport and the Regions (Tree Preservation Order) [2001] EWHC Admin 205; [2002] J.P.L. 33. A larch tree, the subject of a tree preservation order, was located in the grounds of property A. H, the owner of an adjoining property, applied for consent for the tree to be pruned so as to remove the risk overhanging branches posed to his conservatory. R refused the application and $\mathrm{H}$ appealed to the Secretary of State. An inspector recommended that H's appeal should be dismissed. The inspector's report stated that the tree contributed to the general amenity of the area. Further, that it was situated so close to the boundary that removing the overhanging branches would not prevent debris falling onto H's conservatory. The inspector concluded that the amenity benefit of the tree outweighed the inconvenience involved in removing its debris from the conservatory. The Secretary of State refused to accept the inspector's findings and allowed H's appeal. R appealed. Held, allowing the appeal and remitting the matter to the Secretary of State, that the Secretary of State's decision was irrational, and the consent itself was inadequate because it was impossible to determine precisely which operations could be lawfully carried out. The permitted work had not been identified clearly and insufficient reasons had been given for disagreeing with the inspector's recommendations.

R. (on the application of Robin Taylor (t/a David Taylor \& Sons (Farms)) v Secretary of State for the Environment, Transport and the Regions [2001] P.L.C.R. 25. T appealed against the dismissal of his appeal against two enforcement notices requiring him to remove a hard surface and deposits of waste materials from his farm. The enforcement notices alleged that works undertaken by $\mathrm{T}$ amounted to a change of use from agricultural use to agricultural use and use for the unauthorised importation and deposit of waste materials, and in addition to the carrying out of engineering operations, in each case in breach of planning control. Held: the inspector's failure to exercise that power to allow some waste materials to remain on site, in circumstances where the importation of some of the waste material had been reasonable and necessary for agricultural purposes, amounted to an irrational exercise of her discretion, and the requirement to remove the waste would involve $\mathrm{T}$ in unnecessary work and expense.

R. (on the application of Morgan) v Coventry City Council (2001) 4 C.C.L. Rep. 41; [2001] A.C.D. 80.C, who was seriously disabled, challenged the decision of CCC to change the charging structure applicable to day care provision so as to take into account as income that part of higher rate Disability Living Allowance, DLA, payable for night time care. Previously CCC had charged a flat rate for the services they provided but had subsequently introduced a means tested system following a detailed consultation exercise with claimants and other interested parties. Held: it was irrational, unfair and unlawful for CCC to treat monies intended for night time care as being income available for day time care.

R. v Parole Board Ex p. Gordon [2001] A.C.D. 47. G, a mandatory life prisoner, sought judicial review of the parole board's decision not to recommend that he be transferred from closed to open conditions. G contended that the decision was irrational as the evidence suggested that a transfer was appropriate, despite a later finding that there was an unexplored sexual element to G's offending. Held: the decision was unlawful as the parole board had not carried out fully the balancing exercise required of it as it had only considered the risks of $\mathrm{G}$ being 
moved and had not weighed them against the benefits of transfer. Further, the board had erred by treating evidence of R's earlier failure on the pre-release employment scheme as justifying a conclusion that he should not be transferred to open conditions.

R. v Secretary of State for the Home Department Ex p. Jordan [2001] A.C.D. 46. J sought judicial review of the parole board's finding that he was unsuitable for early release. J had been sentenced to six years' imprisonment following a violent attack on his girlfriend whom he had previously stalked and assaulted and contended that the board had erred in failing to take proper account of the probation reports and the fact that he had been monitored outside prison for several months whilst on home leave. Held, granting the application for judicial review and remitting the case, that the parole board's decision that J needed further work on anger management was irrational in view of the conclusion in the probation report that further work was unnecessary.

R. v Criminal Injuries Compensation Board Ex p. T [2001] P.I.Q.R. Q2. T sought judicial review of CICB's refusal to award him compensation for the loss of a leg as a result of a gun shot wound. The Board had concluded that it would be inappropriate to make an award because $\mathrm{T}$ had several previous convictions for robbery and dishonesty offences. T contended that (1) the Board had attached too much weight to the hearsay evidence of a police officer who had not been involved in the investigation into the shooting; (2) the form in which the Board had given the reasons for its decision had been inadequate, and (3) the finding that he had not satisfied the Board that his injury was directly attributable to a crime of violence had been irrational in all the circumstances. Held, granting the application, that (1) the Board had clearly been influenced by the police officer's speculative comments that the shooting may have been drugs related and that $\mathrm{T}$ may have refused to cooperate with the investigating officer; (2) whilst the Board had failed to give extended reasons for its decision until 14 months after the hearing, the oral reasons given at the conclusion of the hearing, which were subsequently confirmed in correspondence, had been sufficient for $\mathrm{T}$ to understand the basis of the decision, and (3) the finding that $\mathrm{T}$ had not shown that his injury resulted from a violent crime had indeed been irrational.

R. (on the application of Tawfick) v Secretary of State for the Home Department [2001] A.C.D. 28. T challenged the Secretary of State's refusal to make an ex gratia compensation award following his wrongful conviction for conspiracy to steal. The conviction had been quashed following an unfair trial, where the judge had attacked T's integrity in open court. The Secretary of State refused to make a payment on the basis that the behaviour of the judge had not amounted to wholly exceptional circumstances under the second limb of the non-statutory scheme. Held, granting the application, that the Secretary of State had applied the wrong test as he had compared the actions of the judge in T's case with the circumstances in R. v Bentley (Derek) [1999] Crim. L.R. 330. The correct test under the second limb of the compensation scheme was not whether the case involved an error as serious as in Bentley, but whether the conduct of the judge amounted to exceptional circumstances. The attack on T's character was wholly exceptional given that $\mathrm{T}$ had appeared in person, the comments were made in the context of a trial for a dishonesty offence and were likely to lead the jury to believe that $\mathrm{T}$ was a cheat. The decision of the Secretary of State was therefore irrational and beyond the range of reasonable responses to the test laid down under the scheme.

\section{NOT UNREASONABLE}

R. (on the application of Taylor) v Secretary of State for the Home Department [2002] EWHC 2761. T applied for judicial review of two decisions of the Secretary of State refusing to pay him compensation following the quashing of his conviction by the Court of Appeal. Held: the Secretary of State's decision could not be classified as Wednesbury unreasonable as he had made a permissible decision, considering all he was required to consider and not considering anything that he should not have considered.

R. (on the application of Bello) v Lewisham LBC [2002] EWHC 1332; [2002] E.H.L.R. 19. B sought judicial review of a decision made by $L$ on April 5, 2000 to enforce a demolition notice under the Building Act 1984 s.36, originally served on B in September 1988. The notice related to a rear extension for which no planning permission or building regulations approval had been obtained. B contended that the decision to enforce the notice after an 11 year delay was Wednesbury unreasonable. Held: the decision was not Wednesbury unreasonable. L had a wide margin of appreciation given the extent of its statutory enforcement powers. R. (on the application of Bonyama) v Secretary of State for the Home Department [2001] EWCA Civ 1353; [2002] Imm. A.R. 234. B, a national of Zaire, later the Democratic Republic of Congo, was injured in the civil war. The Secretary of State decided he should be returned to Belgium for consideration of his asylum claim. B applied for judicial review on the basis that the Secretary of State had failed properly to consider the medical evidence. Held: Held, refusing permission to move for judicial review that, it was plain from the decision letter that the Secretary of State had fully considered the medical evidence and concluded that the Belgian authorities 
would provide appropriate protection against any risks involved; the material did not compel a different conclusion to that reached by the Secretary of State, which was therefore not Wednesbury unreasonable.

R. (on the application of Anne) v Test Valley BC [2001] EWHC Admin 1019; [2002] Env. L.R. 22. A applied for judicial review of the Council's decision not to serve an abatement notice because no statutory nuisance existed. A owned a thatched cottage in an area covered by the Council. A complained that a lime tree growing in a neighbouring property was producing honeydew, mould and mould spores which adversely affected A. Held: there was no basis upon which the conclusions reached by the Council's officer could properly be categorised as irrational or Wednesbury unreasonable.

R. (on the application of Hadfield) v Secretary of State for Transport, Local Government and the Regions [2002] EWHC 1266; [2002] 26 E.G.C.S. 137. H sought to quash the Secretary of State's decision to exercise his power under the Town and Country Planning Act $1990 \mathrm{~s} .77$ to call in an application for planning permission for conversion of agricultural buildings to stables and a dwelling. Held: it was clear that the Secretary of State had had the relevant policy in mind when making his decision as he had in a letter made reference to a Parliamentary answer relating to the selective nature of that policy. His decision was not unreasonable in the Wednesbury sense because the proposed development, although small scale, was in conflict with national Green Belt policy by virtue of its nature and location.

Association of British Civilian Internees (Far East Region) v Secretary of State for Defence [2002] EWHC 2119. The claimant, an association representing internees in Japan during World War II, sought judicial review of the Secretary of State's decision that in order to qualify for an ex gratia compensatory payment of $£ 10,000$, a civilian internee had to be a British subject who had been born in the United Kingdom or a British subject who had a parent or grandparent who had been born in the UK. Held: $t$ was not unreasonable for the Secretary of State to limit eligibility to those with close links to the UK and the criteria were more generous in their ambit than those applied to an earlier compensation scheme; the decision of the Secretary of State could not be said to be unreasonable and accordingly there had been no breach of the common law principle of equality.

R. (on the application of Molinaro) v Kensington and Chelsea RLBC [2001] EWHC Admin 896; [2002] B.L.G.R. 336. M applied for judicial review of the local authority's decision not to allow $M$ to change the use of premises leased by him from the local authority. The lease allowed the premises to be used only as a retail delicatessen, in accordance with local planning policy. Over the years, $\mathrm{M}$ began selling food to be eaten on the premises and applied for planning permission for a change of use. Held: irrationality and breach of fiduciary duty were in the circumstances of this case one and the same. The local authority had been in the best position to judge local planning need and its decision was not so surprising as to be irrational.

R. (on the application of MacNeil) v HMP Lifer Panel [2001] EWCA Civ 448; (2001) 98 L.S.G. 43. M, a convicted murderer who had been released on licence but then recalled to prison following his conviction of a further offence, appealed against the dismissal of his application for judicial review of the decision of the parole board that he should be detained in open conditions for a period of two years before a review was carried out. Held: while a review should take place at reasonable intervals, the unreasonableness of any delay would depend on the facts of the case. The decision to delay the review in M's case for a period of two years was not unreasonable and did not contravene Art.5(4) ECHR.

R. v Secretary of State for Trade and Industry Ex p. Isle of Wight Council (2001) 3 L.G.L.R. 16; [2000] C.O.D. 245. IWC sought judicial review of the Secretary of State's decision not to include the Isle of Wight in the classification of areas to receive development funding under two schemes, (a) Regional Selective Assistance, RSA, under the Industrial Development Act 1982, and (b) Objective 2 proposals under the European Community's structural funds scheme outlined in EC Treaty Art.158 to Art.161. IWC argued that the decision was Wednesbury unreasonable in relation to RSA as SST had failed (1) to give appropriate weight to the economic disadvantages suffered by the Isle of Wight because of its island status, as required by EC Treaty Art.158 (now, after amendment Art.214 EC); (2) to properly take account of the very high levels of unemployment and the factor of insularity, and (3) in relation to Objective 2, IWC, whilst recognising that the Isle of Wight did not meet the criteria for inclusion in Objective 2, argued that SSTI should have put the Isle of Wight forward as a special case because of its high levels of unemployment and its insularity. Held: as the decision involved considerations of national economic policy, the threshold for a finding of Wednesbury unreasonableness was higher than in other matters, and it had not been met by IWC's arguments.

R. (on the application of Jones) v Mansfield DC [2003] EWHC 7; [2003] N.P.C. 5. J applied for judicial review of the local planning authority's decision to grant outline planning permission for the development of an industrial estate opposite her home. $\mathrm{J}$ contended that it had been unreasonable for the planning committee to 
decide that the development was unlikely to have significant environmental effects for the purposes of the Town and Country Planning (Assessment of Environmental Effects) Regulations 1988 Reg.2(1) and Reg.4(1) so that there was no obligation to conduct an environmental impact assessment, EIA, prior to the grant of planning permission. Held: it had not been unreasonable for the local authority to take the view that it could decide on the likelihood of significant environmental effects on the basis of the large body of information available, even though it was not complete. Moreover, there was also considerable material as to the potential impact on bats, but no evidence of their presence on the site and no evidence of loss of other wildlife habitats which could render the local authority's decision unreasonable.

R. (on the application of Persey) v Secretary of State for the Environment, Food and Rural Affairs [2002] EWHC 371; [2002] 3 W.L.R. 704. A number of claimants, all of whom had been affected by the outbreak of foot and mouth disease in 2001, applied for judicial review of the decision of the Government to set up three separate independent inquiries into the outbreak. The three inquiries were to receive evidence mainly in private. The claimants maintained that only an open public inquiry would be sufficient. Held: it was wrong to presume that an open public inquiry would be the remedy for all matters. There was no "uniform practice" as to what form an inquiry would take; it was doubtful that there was a legal presumption that any public inquiry was required to sit openly. It followed that the decision had not been irrational or otherwise unlawful.

R. (on the application of B) v Wakefield Prison Governor [2001] EWHC Admin 917; [2002] 1 F.C.R. 445. B, a discretionary life sentence prisoner, sought judicial review of the prison governor's refusal to grant permission for visits from his young nephew, and the Secretary of State's policy which introduced child protection measures for prison visits. B had a previous conviction for the gross indecency of an eight year old boy and one for the indecent assault of a boy in a detention centre. Held: the weight to be attached to factors under consideration was a matter for the decision maker. The governor's decision was not irrational and he had been entitled to conclude that B's sister's child care difficulties should not outweigh considerations of her son's welfare and to attach limited weight to the observations of the social workers.

Mansard County Homes Ltd v Secretary of State for the Environment, Transport and the Regions [2001] EWHC Admin 704; [2002] P.L.C.R. 20. M sought to quash a decision of the local authority planning inspector dismissing an appeal against a refusal to grant outline planning permission for a residential development which would have involved severance of a disused railway line. The inspector had decided that the proposal was contrary to the aims and intentions of those elements of the local structure plan and the emerging local plan that sought to safeguard future public transport options. These policies derived from Planning Policy Guidance Note 13, PPG13, which stated at paragraph 5.8 that disused transport routes should not be "unnecessarily severed by new buildings and non transport land uses, especially where there [was] a reasonable chance that such routes [might] be put to use in the future". Held: $t$ was entirely comprehensible that the Secretary of State would wish to keep future transport options open and as such PPG13 could not be described as irrational or unreasonable. Having established the materiality of PPG13, it was up to the planning inspector to accord appropriate weight to the policy.

BT3G Ltd v Secretary of State for Trade and Industry [2001] EWCA Civ 1448; [2001] 3 C.M.L.R. 61. BT and OO, telecommunications companies, appealed against the refusal ([2001] Eu. L.R. 325) of their application for judicial review of decisions of the Secretary of State concerned with the auction of licences for the "third generation" of mobile telephones, also known as the "Universal Mobile Telecommunications System" or UMTS. Under the auction rules, each licence had to be paid for as soon as it was granted. OO and BT were each granted a licence and paid the required fee. Other applicants, $\mathrm{V}$ and $\mathrm{O}$, were associated companies and whilst their licence bids were accepted, the rules required that as a precondition of the grant of a licence they must cease to be associated. The resultant delay whilst $\mathrm{V}$ divested itself of $\mathrm{O}$, meant that the licences were not granted for approximately four months which resulted in a saving to $\mathrm{V}$ and $\mathrm{O}$ on the substantial cost of financing the licence fee when compared with BT and OO. Held: Any bidder could have become subject to a precondition at any stage in the bidding process and the auction rules would have been applied in exactly the same way to any such bidder. Having regard to the Secretary of State's paramount concern to ensure that there should be no association between licence holders, his conduct could not be regarded as in any way irrational or unfair.

R. (on the application of United Kingdom Renderers Association Ltd) v Secretary of State for the Environment, Transport and the Regions [2001] EWHC Admin 675; [2002] Env. L.R. 21. An association representing British animal renderers, sought judicial review of a guidance note issued by the Secretary of State in order to further the aims of the Environmental Protection Act 1990. U complained that the provisions of the guidance note, requiring renderers to use all due diligence and take all reasonable steps to prevent the escape of offensive odours beyond the boundary of the processing site, conflicted with the provisions of the Act which required that the best available techniques, not entailing excessive cost, were to be used. Held: the Secretary of State was not 
required to demonstrate any technical or scientific basis for the guidance, therefore a failure by the Secretary of State to demonstrate a technical or scientific basis for the compatibility of an odour boundary condition with the "best available techniques, not entailing excessive cost," test did not mean that the guidance had been shown to be irrational and unlawful.

Terry v Craze [2001] EWCA Civ 1094; [2002] Q.B. 312. T appealed against the refusal of her application for judicial review ([2001] Q.B. 559) of the coroner's decision not to hold an inquest into the death of her husband, who had been exposed to asbestos at work for many years. The coroner had obtained a post-mortem examination report under the Coroners Act 1988 s.19 which stated that the cause of death was not asbestosis. Held: in circumstances where the coroner refused to hold an inquest, the court did not have the power to order one unless he had erred in law or his conclusion as to fact was irrational. In the instant case, the lower court had not erred in upholding the decision of the coroner that there was no reasonable cause to suspect that T's husband had died of asbestosis.

R. (on the application of Barker) v Waverley BC [2001] EWCA Civ 566; [2002] 1 P. \& C.R. 6. WBC and BAE appealed against an order quashing WBC's decision to remove a condition attached to BAE's planning permission in respect of an aerodrome site, which stated that the land would revert to agricultural use following BAE's cessation of use, of which notice had been given. WBC's decision was quashed following an appeal by B, the local residents, on the grounds that an immaterial consideration had been taken into account, the removal of the condition was irrational, and that B had a legitimate expectation that the condition would continue on account of the length of time it had been in place. Held, allowing the appeal, that the potentially immaterial consideration was only referred to in one paragraph of the planning officer's report and it was unlikely that it had influenced members, given that it was their role to consider planning issues. Further, the removal of the condition was not irrational because it was not beyond the responses of a reasonable decision maker given the considerations highlighted in the planning officer's report,

R. (on the application of Tucker) v Secretary of State for Social Security [2001] EWCA Civ 1646; [2002] H.L.R. 27. T contended that (1) the Secretary of State's decision to amend the Regulations as he did was Wednesbury unreasonable and disproportionate since there was no basis for the underlying assumption that a parent should be responsible for providing accommodation for his child; (2) there should have been a reverse burden of proof provision and that it was unreasonable not to provide transitional provisions excluding $\mathrm{T}$, who was a recipient of housing benefit under the previous Regulations, and who would have ordered her life accordingly. Held, dismissing the appeal, that (1) the judge was correct in finding that irrationality was not proved and that assumption underlying Regulation 7(1)(d)'s was based on a rational belief that where the tenant was a parent and carer of the landlord's child, the landlord would not generally consider the tenancy in the usual commercial manner; (2) the absence of a reverse burden of proof was not unreasonable as it was hard to refute evidence of a tenancy provided by the tenant or landlord.

R. (on the application of Wirral MBC) v Chief Schools Adjudicator [2001] E.L.R. 574. WMBC challenged a decision of $\mathrm{C}$ that its proposals to carry out selection tests for entry to grammar schools in its area, prior to the expression by parents of their preference as to secondary school, was unfair and therefore unlawful. C had found that the testing was part of the admissions arrangements and that the procedure would adversely affect parents with a preference for the comprehensive schools in the area which were oversubscribed. WMBC contended that the decision was irrational. Held, refusing the application for judicial review, the adjudicator's decision that one group of parents should not have a chance of its first preference without risking its second, although apparently harsh to the group which lost a benefit, was not irrational.

R. v Legal Aid Board Ex p. Burrows [2001] EWCA Civ 205; [2001] 2 F.L.R. 998. B, who had acted for the mother of a child in connection with an application for a care order under the Children Act 1989 s.31, appealed against the refusal of his application for judicial review of the decision of the Legal Aid Board to limit the costs payable to him to the sum of $£ 5,000$, that being the costs limitation set under the relevant legal aid certificate. Held: the imposition of financial limitations on legal aid certificates ensured that no more than was reasonable and proportionate was spent on publicly funded civil litigation and could not therefore be described as irrational.

R (on the application of Assisted Reproduction and Gynaecology Centre) and another v Human Fertilisation and Embryology Authority [2002] EWCA Civ 20, [2003] 1 F.C.R. 266. A sought permission to seek judicial review of a decision by HFEA not to authorise the implantation of more than three embryos in a particular patient. The HFEA code of practice stipulated that no more than three embryos were to be implanted in a woman in any single fertilisation cycle. A contended that, whilst the general prescription on the numbers of embryos to be transferred was reasonable, it was nevertheless appropriate to authorise a departure from the normal rule in the 
case of a patient who had undergone eight previous unsuccessful attempts at in vitro fertilisation. Held, refusing the application, that the court had no authority to intervene to quash the decision of HFEA in circumstances where careful and thorough consideration had been given to the matter and an opinion provided that was plainly rational. The subject matter under consideration formed part of a rapidly developing area of scientific knowledge and debate. It was not the function of the court to enter into scientific debate nor to adjudicate upon the merits of the decisions made by the authority or any advice that it might give. Whilst the decisions of the authority were open to judicial review, they were only amenable to such scrutiny in circumstances where the authority had either exceeded or abused its powers.

R. v Collins Ex p. Brady 2000] Lloyd's Rep. Med. 355. B, a prisoner on hunger strike, applied for judicial review of the decision of $\mathrm{C}$, his responsible medical officer, and AHA, the hospital in which he was held, to force feed him. The decision had been purportedly made pursuant to the Mental Health Act 1983 s.63. Held, refusing the application, that (1) where the decision of a responsible medical officer to administer treatment without consent pursuant to s.63 of the Act was the subject of a challenge, the appropriate test was that of the reasonableness of the decision in the Wednesbury sense rather than the "precedent fact" test, R. v Secretary of State for the Home Department Ex p. Khawaja [1984] A.C. 74 distinguished. Given that s.63 was a derogation from the human rights of self determination and bodily integrity, the appropriate Wednesbury test was that established in R. v Ministry of Defence Ex p. Smith [1996] Q.B. 517.

R. (on the application of Gravett) v Criminal Injury Compensation Appeals Panel [2001] EWHC Admin 1193; (2002) 67 B.M.L.R. 21. G sought judicial review of C's decision that an injury for which she made a claim was not a direct result of a crime of violence. $\mathrm{G}$ was a nurse, and alleged that she had been assaulted by $\mathrm{W}$ at his home in the course of her duties. The police had investigated the incident, and an officer had visited $\mathrm{W}$ with the purpose of arresting him. However, no arrest was made and no charges were brought. The crime report indicated that there was a decision not to prosecute in the public interest because $\mathrm{W}$ was senile. Held, refusing the application, on the facts there was no proper basis for suggesting that aspects of the evidence had been given improper weight or other reasons for suggesting that no reasonable tribunal could have come to the conclusion that $\mathrm{C}$ had done. 